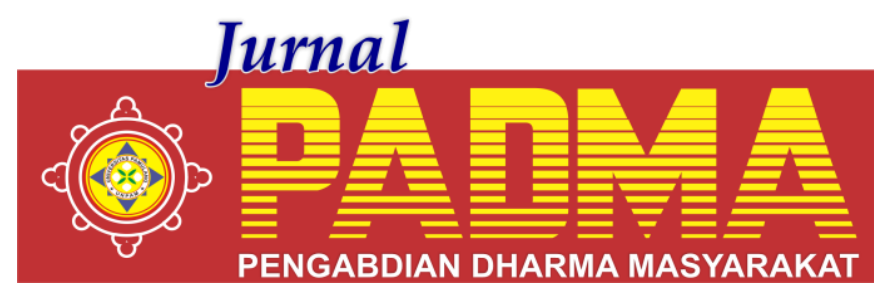

VOLUME 1, NOMOR 3, JULI 2021

\title{
PENYULUHAN BAHAYA PORNOGRAFI BAGI ANAK-ANAK YATIM DAN DHUAFA
}

\author{
${ }^{1 *}$ Ahmad Wawan, ${ }^{2}$ Lili Nurkhasanah, ${ }^{3}$ Pretiwan Putri, ${ }^{4}$ Sri Melinda, 5 Irawati \\ Universitas Pamulang, Tangerang Selatan, Banten, Indonesia \\ *Ahmadwawan789@gmail.com
}

\begin{abstract}
Abstrak
Tujuan Pengabdian Kepada Masyarakat (PKM) Mahasiswa ini dilakukan adalah untuk memberikan pengetahuan dan pemahaman kepada anak-anak Yatim dan Dhuafa yang beralamat di Desa Cidokom, Kec.Gunung Sindur, Kab.Bogor, Jawa Barat. Adapun Metode kegiatan ini adalah mendatangi Anak-anak yatim dan Dhuafa tersebut dan memberikan pemahaman dan pengetahuan bagi anak-anak tentang bahaya pornografi. Hasil dari kegiatan tersebut adalah para peserta lebih memahami dan mengetahui apa itu pornografi, serta mengetahui dampak negatif yang ditimbulkan dari paparan pornografi, sehingga ke depan anak-anak di desa cidokom dapat menghindarkan diri dari keterpaparan pornografi dan terhindar dari kemungkinan menjadi pelaku kekerasan seksual di masa mendatang.
\end{abstract}

Kata Kunci: Pornografi, Anak-Anak Yatim Dan Dhuafa

\section{Abstract}

The purpose of this student's devotion to the community (PKM) was to give knowledge and understanding to the orphans and to dhuafa at the village of cidokom, kec. Mount sinur, kab. Bogor, west Java. As for this method of activity, it was to visit the orphans and dhuafa and give the children an understanding and knowledge of the dangers of pornography. The result of the activity is that participants better understand and know what pornography is, and know the negative effects of exposure to pornography, so that in the future children in cidokom village can avoid exposure to pornography and avoid the possibility of becoming the perpetrators of sexual violence in the future.

Key Words: Pornography, Orphan And Dhuafa

\section{PENDAHULUAN}

Kehadiran teknologi komunikasi berbasis digital dan penggunaannya yang semakin masif membawa sejumlah implikasi. Di satu sisi, perkembangan media digital berdampak positif, seperti menyediakan kemudahan akses atas informasi, memudahkan komunikasi tanpa perlu mengkhawatirkan jarak dan waktu, serta berkontribusi terhadap pertumbuhan demokrasi. Namun di sisi lain, perkembangan media digital juga tidak terlepas dari dampak negatif. Salah satunya terkait produksi, distribusi dan konsumsi konten pornografi.

Pornografi yang pada awalnya hanya didistribusikan melalui video Betacam kemudian keping Digital Versatile Disk (DVD) maupun Versatile Compact Disk (VCD), saat ini dapat dikonsumsi melalui laptop, tablet, smartphone, serta perangkat digital lainnya dengan didukung oleh koneksi internet. Sejumlah riset menunjukkan bahwa akses konten pornografi paling banyak melalui smartphone.

Keberadaan pornografi dalam kehidupan masyarakat Indonesia tidak dapat ditutupi lagi. Seiring dengan kemajuan teknologi dan media komunikasi, pornografi dapat ditemukan oleh berbagai kalangan masyarakat. Bagi masyarakat yang mampu mengakses internet dan ada jutaan link yang berkaitan dengan pornografi yang masih dapat diakses dari website. Tidak menutup kemungkinan bahwa kemudahan dalam mengakses pornografi dapat pula diakses oleh anak-anak. Hal ini membawa pengaruh buruk bagi perkembangan anak terutama mengenai pemahaman anak terhadap seks sebagai bagian dari seksualitas.

Jika dihadapkan pada anak-anak, pornografi adalah ancaman serius bagi kesalihan mereka. Terpapar pornografi berarti satu langkah terjerumus kerusakan moral. Paparan pornografi pada anak-anak 
di khawatirkan merusak pertumbuhan psikologis dan biologis mereka. Terpapar dengan pornografi bisa menyebabkan kecanduan atau ketergantungan menonton pornografi. Kebiasaan anak dalam mengakses video porno dapat menimbulkan suatu hal ketagihan atau kecanduan.

Bahaya lain dari maraknya pornografi seperti menyangkut resiko gangguan kesehatan, psikologis, pendidikan, dan rontoknya berbagai nilai moral masyarakat. Rahmawati (2012: 4) menyatakan "Aktivitas anak yang selalu terpapar dengan berbagai produk kebudayaan yang tanpa filter seperti tayangan-tayangan porno, film dan bacaanbacaan bertema seks ikut memberi andil dalam perkembangan biologis dan psikologis anak.

Efek pornografi terhadap anak terdiri dari empat tahapan yang meliputi adiksi, eskalasi, desensitisasi dan act out (Supriati \& Fikawati, 2009). Adiksi adalah tahap kecanduan, yaitu keinginan untuk mengkonsumsi pornografi kembali timbul setelah terpapar oleh konten tersebut sebelumnya. Berikutnya adalah eskalasi yaitu munculnya kebutuhan untuk mengonsumsi konten pornografi dengan muatan materi seks yang lebih berat daripada sebelumnya. Tahap yang ketiga, desensitisasi, merupakan tahap ketika materi seks yang awalnya tabu, tidak bermoral dan merendahkan martabat manusia secara perlahan dianggap sebagai sesuatu yang biasa, bahkan pada tahap ini, seseorang dapat menjadi tidak sensitif terhadap korban kekerasan seksual. Hal ini juga senada dengan pandangan ahli yang melihat pornografi sebagai bentuk subordinasi terhadap perempuan. Tahap terakhir, act out, adalah tahapan yang dapat dikategorikan sebagai tahapan yang paling nyata karena pada tahap ini, seseorang dapat mengaplikasikan perilaku seksual pornografi yang selama ini hanya dikonsumsinya.

Hasil studi lainnya yang dimuat di situs The Conversation menunjukkan bahwa anak muda yang mengonsumsi pornografi cenderung akan mengembangkan perilaku seksual abusif. Mereka yang pernah menyiksa orang lain secara seksual mengatakan bahwa jika saja mereka menerima bantuan terkait permasalahan mereka dengan pornografi, maka kecenderungan mereka untuk berlaku abusif akan berkurang (McKibbin, Hamilton, \& Humphreys, 2016).

Pemerintah Indonesia melalui Kementerian Komunikasi dan Informatika (Kemenkominfo) memang telah berupaya membatasi distribusi konten pornografi dengan melakukan pemblokiran atas sejumlah situs yang menampilkan pornografi melalui program Internet Positif, di samping pemblokiran atas situs-situs selain pornografi yang juga dianggap memiliki dampak negatif. Namun upaya ini nampaknya belum berhasil sepenuhnya mengatasi peredaran pornografi di Internet. Hal ini dapat dilihat dari munculnya beragam tutorial di internet untuk membobol Internet Positif. Selain itu, Kemenkominfo pun menyatakan bahwa konten pornografi, seperti di media sosial, memang tidak dapat diblokir secara total (Nursalikah, 2017). Selain restriksi melalui program Internet Positif, pemerintah juga sebenarnya telah memiliki regulasi untuk mengatasi penyebaran dan dampak negatif pornografi khususnya bagi anak-anak dan remaja, yaitu Undang-Undang Nomor 44 Tahun 2008 tentang Pornografi.

\section{METODE}

Metode pelaksanaan kegiatan pengabdian kepada masyarakat ini dilakukan dengan mendatangi Anak-anak di Desa Cidokom tersebut untuk memberikan pemahaman dan pengetahuan bagi anakanak tentang bahaya pornografi. Pelaksanaan pengabdian kepada masyarakat dilakukan secara langsung pada tanggal 21 April 2021. Metode kegiatan pengabdian yang digunakan adalah metode ceramah dan diskusi yang dipilih untuk menyampaikan materi. Pemanfaatan laptop dan Liquid Crystal Display (LCD) membantu peserta pelatihan lebih mudah memahami dan mengingat materi pelatihan relatif banyak dengan waktu pelatihan yang terbatas. 


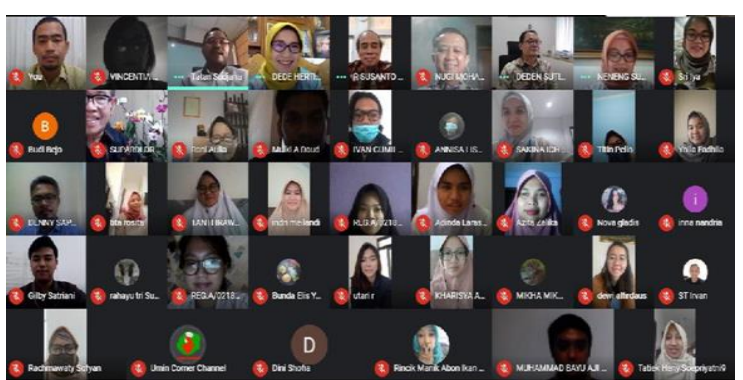

Gambar 1. Pelaksanaan Kegiatan Melalui Google Meet

\section{HASIL DAN PEMBAHASAN}

Penggunaan media oleh anak- anak hingga remaja, baik televisi maupun internet sudah menjadi sebuah kebutuhan, termasuk penggunaan gadget, sebagai kebutuhan dikalangan masyarakat. Televisi diberi banyak sebutan yang tidak semuanya baik bergantung pada sudut pandang seseorang, televisi bisa menjadi "jendela dunia" tapi bisa juga menjadi monster dunia (Santrock, 2007, p. 24). Pengaruh negatif dari media TV terhadap perkembangan anak, menjadikan anak sebagai pembelajar pasif, memunculkan stereotif, memberikan model kekerasan, dan menyajikan mereka pandangan yang tidak realistis kepada dunia. Kekerasan televisi bukan satu satunya penyebab agresi anak, namun kebanyakan ahli setuju bahwa televisi dapat mendorong agresi dan perilaku anti sosial. Ada juga keprihatinan anak-anak yang bermain video game, karena bermain game kekerasan akan dapat meningkatkan agresivitas seseorang (Dill \& Dill, 1998).

Apriadi, 2013 dalam (Nur Anisah, 2016) situs porno dalam satu menit bisa memunculkan sekitar 30.000 page (halaman) pornografi. Tayangan pornografi yang ditampilkan di TV atau gadget dan internet dapat mempengaruhi sikap dan perilaku seksual anak. Saat ini terjadi peningkatan penggunaan komputer dan internet oleh anak-anak secara dramatis menimbulkan keprihatinan pada orang tua karena tidak dapat memantau informasi yang diakses oleh anak mereka. Pada satu sisi tingkat pembelajaran teknologi pada anak semakin meningkat, meski tidak meningkatkan pembelajaran aktif dan kostruktivis yang dibutuhkan anak. Faktor budaya ini lebih banyak diperankan oleh komunitas atau masyarakat dimana anak tersebut berada.
Pornografi didefinisikan sebagai semua bentuk media eksplisit yang menampilan, mengekspos budaya atau keragaman hubungan yang sangat seksual, seperti menunjukkan alat kelamin dan kegiatan seksual secara terbuka (tanpa disembunyikan), dimana tujuan utamanya adalah untuk membangkitkan gairah orang yang melihat (American Psychological Association, 2007; Malamuth et al., 2001; Peter \& Valkenburg, 2007). Sebuah survey Institute for Public Policy Research (IPPR) menjelaskan bahwa dari 500 remaja , diketahui bahwa $77 \%$ anak laki-laki dan $83 \%$ anak perempuan mengakui bahwa sangat mudah bagi kaum muda untuk secara tidak sengaja melihat pornografi saat mereka dengan terhubung internet (Saint John Vianney Centre, 2018).

Penelitian mengenai pornografi (Bulkley, 2013) menunjukkan bahwa pada tahun 2013 usia rata-rata seorang anak pertama kali melihat pornografi internet adalah 11 tahun, dimana terdapat sebanyak $70 \%$ anak laki-laki telah menghabiskan setidaknya 30 menit berturut-turut melihat pornografi on-line setidaknya pada satu kesempatan; $35 \%$ anak laki-laki telah melakukan ini setidaknya sepuluh kali; 83\% anak laki-laki telah melihat seks berkelompok di internet; $67 \%$ anak-anak mengaku membersihkan sejarah internet mereka untuk menyembunyikan aktivitas online mereka; $0 \%$ pengguna pornografi melaporkan kecanduan.

Direktorat Pembinaan Pendidikan Keluarga Kementerian Pendidikan dan Kebudayaan menjelaskan bahwa kemajuan teknologi informasi dan komunikasi memengaruhi jumlah anak-anak yang terpapar video porno, dan biasanya video porno dapat dengan mudah ditemukan anak di game, majalah, media sosial, dan jejaring internet (Direktorat Pembinaan Pendidikan Keluarga, 2017).

Paparan pornografi pada anak-anak terutama didapat melalui intenet yang diperburuk dengan "lifestyle" dan kurangnya pengawasan, tidak ada komunikasi, tuntutan terlalu tinggi, kekerasan pada anak, tidak tahu potensi anak, serta diskriminasi dari orang tua dan lingkungan dapat memicu remaja untuk dapat terpapar pornografi. Berdasarkan survey yang dilaksanakan 
Kemenkes tahun 2017 sebanyak 94\% siswa pernah mengakses konten porno yang diakses melalui komik sebanyak 43\%, internet sebanyak 57\%, game sebanyak 4\%, film/TV sebanyak 17\%, Media sosial sebanyak 34\%, Majalah sebanyak 19\%, Buku sebanyak $26 \%$, dan lain-lain $4 \%$.

Beberapa literatur menjelaskan bahwa terdapat beberapa faktor yang menyebabkan anak terpapar pornografi (Direktorat Pembinaan Pendidikan Keluarga, 2017; Semai, 2015; Strasburger et al., 2010; Tim Sejiwa, 2018), antara lain:

a. tidak sengaja melihat pornografi yang muncul saat menggunakan gadget orangtua atau saat mengakses internet;

b. menerima dan membuka pesan teks, foto, atau video seksual di media sosial;

c. memiliki rasa ingin tahu atau penasaran yang tinggi, sehingga membuat anak mencoba mengakses situs bermuatan pornografi;

d. terpengaruh dengan ajakan atau bujuk rayu teman sebaya dan lingkungan sekitarnya;

e. perasaan BLAST, yaitu: Bored (Jenuh), Lonely (Kesepian), Angry (Marah), Stressed (Stres), Tired (Lelah);

f. kurang pendidikan agama, khususnya pembelajaran karakter dan penanaman akhlak dari sekolah;

g. kurangnya kesadaran orang tua terhadap pentingnya perhatian orang tua dalam pengawasan media yang digunakan anak.

Pornografi merupakan adiksi baru yang tidak tampak pada mata, tidak terdengar oleh telinga, namun menimbulkan kerusakan otak yang permanen bahkan melebihi kecanduan narkoba. Perlunya pengawasan pada anak-anak sehingga dapat mencegah dan menyelamatkan mereka dari bahaya pornografi. Berikut ini ada beberapa cara yang bisa dilakukan untuk mencegah anak terkena pornografi :Mendampingi anak ketika mengakses

a. Memberikan pemahaman anak tentang internet sehat dan aman

b. Memasang aplikasi pengaman pada gadged nya internet

c. Memberikan pendidikan seks sesuai dengan usia perkembangan

d. Apabila anak ketahuan mengakses situs pornografi, orangtua harus mengajak anak berdialog dan menjelaskan dampak pornografi

e. Mengenali teman dan lingkungan sekitar anak

f. Memberikan perhatian, kasih sayang dan penghargaan terhadap anak

g. Menyepakati aturan yang dibuat bersama antara orangtua dengan anak dalam penggunaan gadget.

\section{PENUTUP \\ KESIMPULAN DAN SARAN}

Dari paparan yang telah disampaikan terkait pelaksanaan kegiatan PKM Mahasiswa Prodi Manajemen Universitas Pamulang, yang bertempat di Desa Cidokom, Kec. Gunung Sindur, Kab.Bogor, Jawa Barat, mampu mendorong anak-anak dalam memanfaatkan teknologi saat ini untuk hal yang bermanfaat. Pentingnya pemahaman tentang bahaya pornografi bagi anak-anak akan memberikan dampak yang baik untuk masa depan mereka. Dengan memberikan pengetahuan tentang dampak negatif yang ditimbulkan dari pornografi anak-anak akan mempersiapkan diri dan mencegah dirinya untuk tidak mengkonsumsi konten-konten pornografi.

Pengawasan dari orang dewasa juga sangat dibutuhkan anak, karena pengalaman yang tidak tepat pada anak dapat mengembangkan persepsi yang salah tentang pornografi pada anak, dan hal ini dapat membuat anak kecanduan video porno, mengalami penyimpangan seks, hingga menjadi pelaku pelecehan atau kekerasan seksual di masa mendatang. Dengan begitu perlu memberikan pemahaman tentang bahaya pornografi sejak dini sehingga kedepannya anak-anak akan menggapai masa depan yang lebih baik dan menjadi anak-anak yang cerdas dan berkarakter.

\section{DAFTAR PUSTAKA}

Anggraeni, T., \& Maulidya, E. N. (2020). Dampak Paparan Pornografi Pada Anak Usia Dini. Jurnal Ilmiah Pendidikan Anak Usia Din, Vol.3, No.1.

Hermawati, R., Sugiyarti, L., Handayani, R., Sunarsi, D., Alfiah, S., \& Maddinsyah, A. (2020). The Effect of Trilogy Leadership Style and Organization Culture on School Performance: 
evidence form Indonesian Senior High

School. PalArch's Journal of Archaeology of Egypt/Egyptology, 17(6), 8512-8537.

https://sardjito.co.id/2019/10/30/dampakpornografi-bagi-kesehatan-padaremaja-apakah-berbahaya/, diakses 11 Juni 2021

Murni, R., Setiawan, H. H., Sumarno, S., Kurniasih, A., Astuti, M., Roebyantho, H., et al. (2018). Dampak Media Berkonten Pornografi Terhadap Anak. Jakarta: Pusat Penelitian dan Pengembangan Kesejahteraan Sosial.

Nurjaya, N., Sunarsi, D., Effendy, A. A., Teriyan, A., \& Gunartin, G. (2021). Pengaruh Etos Kerja Dan Disiplin Kerja Terhadap Kinerja Pegawai Pada Dinas Kehutanan Dan Perkebunan Kota Bogor. JENIUS (Jurnal Ilmiah Manajemen Sumber Daya Manusia), 4(2), 172-184.

Pambudhi, A. S. (2019). Mengatasi Kecanduan Tayangan Porno Melalui Konseling Behavioristik Teknik Pengondisian Aversi Pada Anak Desa Sarirejo Pati. Skripsi.

Pawar, A., Sudan, K., Satini, S., \& Sunarsi, D. (2020). Organizational Servant Leadership. International Journal of
Educational Administration, Management, and Leadership, 63-76.

Rachmaniar, Prihandini, P., \& Janitra, P. A. (2018). Perilaku Penggunaan Smartphone dan Akses Pornografi di Kalangan Remaja Perempuan. Jurnal Komunikasi Global, Vol.7, No.1.

Rachmaniar, Prihandini, P., \& Janitra, P. A. (2018). Perilaku Penggunaan Smartphone dan Akses Pornografi di Kalangan Remaja Perempuan. Jurnal Komunikasi Global, Vol.7, No.1.

Sudrajat, A. (2006). Pornografi Dalam Perspektif Sejarah. Humanika, Vol.6, No.1.

Sunarsi, D., Akbar, I. R., Rozi, A., Khoiri, A., \& Salam, R. (2021, January). The Influence of Motivation and Work Discipline on Employee Performance at the Yogyakarta Tourism Service. In Proceeding The First International Conference on Government Education Management and Tourism (Vol. 1, No. 1, pp. 1-7).

Wilandari, D. F., Sunarsi, D., \& Mas'adi, M. (2021). Pengaruh Penilaian Kerja Terhadap Kinerja Karyawan Pada PT. Jaya Mandiri Rekabuana di Cilandak. Jurnal Ekonomi Efektif, 3(2). 